\title{
LAPAROSCOPIC APPENDECTOMY DOES NOT INCREASE THE RATE OF NEGATIVE APPENDECTOMY ALONG WITH A LOWER RATE OF PERFORATED APPENDICITIS - RESULTS IN 1899 PATIENTS AT ZAGREB UHC
}

\author{
Goran Augustin ${ }^{1}$, Zrinka Čižmešija ${ }^{2}$, Jurica Žedelj ${ }^{1}$, Igor Petrović ${ }^{1}$, \\ Vanja Ivković ${ }^{3}$, Anko Antabak ${ }^{1}$, Davor Mijatović ${ }^{1}$ and Mate $\check{S}^{2}$ kegro ${ }^{1}$ \\ ${ }^{1}$ Department of Surgery, Zagreb University Hospital Centre and School of Medicine, \\ University of Zagreb, Zagreb, Croatia; ${ }^{2}$ School of Medicine, University of Zagreb (cand. med.), Zagreb, Croatia; \\ ${ }^{3}$ Department of Internal Medicine, Zagreb University Hospital Centre, Zagreb, Croatia
}

\begin{abstract}
SUMMARY - Laparoscopic appendectomy is the method of choice of many professional societies owing to its many advantages. The question arises whether surgeons urge more easily to laparoscopic exploration due to its less invasiveness, faster recovery and adequate exploration of the entire abdominal cavity than to observation in unequivocal cases. This retrospective analysis (2009-2016) included 1899 patients undergoing laparoscopic (lap) or gridiron intra-abdominal approach treated at Zagreb University Hospital Centre. The analysis included total negative appendectomy, negativenegative appendectomy (normal appendix and no other pathology found), and negative-positive appendectomy (normal appendix but another pathology found) in children ( $\leq 16$ years) and adults. There was no statistically significant difference in the rates of negative appendectomy (children) - lap vs. open ( $\mathrm{p}=0.24)$; negative appendectomy (adults) - lap vs. open ( $\mathrm{p}=0.15)$; negative-negative appendectomy (children) - lap vs. open ( $\mathrm{p}=0.36)$; negative-negative appendectomy (adults) - lap vs. open $(\mathrm{p}=0.21)$; negative-positive appendectomy (children) - lap vs. open $(\mathrm{p}=0.53)$; negative-positive appendectomy (adults) - lap vs. open ( $\mathrm{p}=0.56)$; and laparoscopy group negative appendectomy in children $v s$. adults $(\mathrm{p}=0.56)$. There was a statistically significantly higher perforation rate with the open approach in total $(\mathrm{p}<0.0001)$, in children $(\mathrm{p}<0.0001)$ and in adults $(\mathrm{p}=0.02)$. There was no statistically significant difference between adults and children in the perforation rate with laparoscopic approach $(p=0.24)$ and perforation rate with open approach $(p=0.29)$. Results confirmed that there was no statistically significant difference in the rate of negative appendectomy in all subgroups. It is concluded that laparoscopic appendectomy should be offered as the method of choice in any patient population with suspicion of acute appendicitis.
\end{abstract}

Key words: Appendicitis; Appendectomy; Laparoscopy; Croatia

\section{Introduction}

Appendectomy is one of the most common emergency abdominal surgical procedures. Lifetime risk of

Correspondence to: Assist. Prof. Goran Augustin, $M D, P h D$, Department of Surgery, Zagreb University Hospital Centre, Kišpatićeva 12, HR-10000 Zagreb, Croatia

E-mail: gaugusti@kbc-zagreb.hr

Received October 2, 2017, accepted May 16, 2018 acute appendicitis is $7 \%{ }^{1}$. Although an ever increasing number of articles on antibiotic treatment for certain, well-defined early and non-obstructive types of acute appendicitis has been published ${ }^{2,3}$, all the world's emergency and surgical societies still recommend appendectomy when acute appendicitis is suspected ${ }^{4-6}$. Despite the progress in diagnostic methods, the sensitivity and specificity of either method or combination 
of methods have not reached 100\% for the diagnosis of acute appendicitis. In other words, in a certain percentage, there are cases when normal appendix is found during the operation. Some studies report a higher rate of negative appendectomy with laparoscopic exploration ${ }^{7}$, whereas in others there is no difference between laparoscopic and open approach. There are studies where the rate of negative appendectomy was lower in the laparoscopic group, both in the general ${ }^{8}$ and pregnant populations ${ }^{9}$. Given the possibility of more precise exploration of the entire peritoneal cavity, as well as minimal invasiveness and rapid recovery after laparoscopic approach, the question arises whether the surgeon makes the indication for exploration earlier in uncertain cases. The final question which this study attempted to answer is whether laparoscopic approach results in a higher rate of negative appendectomy.

\section{Patients and Methods}

This retrospective analysis included data on patients that underwent appendectomy at Zagreb University Hospital Centre in the period from January 1, 2009 to December 31, 2016. Data on the number of procedures each year were collected together with basic demographic data (age and sex) and classified according to the surgical approach (laparoscopic, McBurney's incision, median laparotomy) and the existence of perforated appendicitis. According to age, patients were divided into the groups of children (age $<16$ years) and adults (age $>16$ years). A specimen of the resected appendix was sent for histopathologic analysis by light microscopy, along with the degree of inflammation (phlegmonous, gangrenous, perforated appendicitis). In this study, endoappendicitis was neither defined nor used as confirmation of developing appendicitis. If another intraoperative pathology was found, it was resected and the specimen was sent for histopathologic analysis.

The term 'negative' appendectomy or 'negative' finding applied to neat histopathologic finding of appendix without signs of inflammation. As in some cases some other pathology was detected, definitive finding was divided into two subgroups, as follows: negative-negative finding defined as normal appendix and no other pathology found; and negative-positive finding defined as normal appendix, but another intra- peritoneal pathology was confirmed that required immediate surgery.

\section{Results}

During the observed period (2009-2016), a total of 2041 appendectomies were performed. Appendectomies initiated with median laparotomy (and clear intraperitoneal pathology) were excluded (142 patients), then 1899 appendectomies remained. Of these, 649 appendectomies ( 377 male and 272 female) were pediatric, while the remaining 1250 cases were adults (663 male and 587 female). Of these, 1478 (77.8\%) procedures were initiated laparoscopically and the remaining $421(32.2 \%)$ procedures by McBurney's incision. Table 1 shows total negative appendectomy rate, Table 2 negative-negative appendectomy rate, and Table 3 negative-positive appendectomy rate in both laparoscopic and open approaches. The following results were recorded: negative appendectomy rate (children) - lapararoscopy (lap) vs. open: $16.4 \%$ vs. $12.6 \%$ $(\mathrm{p}=0.24)$; negative appendectomy rate (adults) - lap vs.

Table 1. Negative appendectomies by surgical approach in pediatric and adult population (2009-2016)

\begin{tabular}{|l|l|l|l|}
\hline \multirow{2}{*}{ Age (yrs) /Approach } & \multicolumn{3}{|l|}{} \\
\cline { 2 - 4 } & Yes & No & Total \\
\hline$<16$ & 100 & 549 & 649 \\
McBurney & 21 & 146 & 167 \\
Laparoscopy & 79 & 403 & 482 \\
\hline$>16$ & 215 & 1035 & 1250 \\
McBurney & 36 & 218 & 254 \\
Laparoscopy & 179 & 817 & 996 \\
\hline Grand total & 315 & 1584 & 1899 \\
\hline
\end{tabular}

Table 2. Negative-negative appendectomies by surgical approach in pediatric and adult population (2009-2016)

\begin{tabular}{|l|l|l|l|}
\hline \multirow{2}{*}{ Age (yrs)/Approach } & \multicolumn{3}{|c|}{} \\
\cline { 2 - 4 } & Yes & No & Total \\
\hline$<16$ & 71 & 578 & 649 \\
McBurney & 15 & 152 & 167 \\
Laparoscopy & 56 & 426 & 482 \\
\hline$>16$ & 152 & 1098 & 1250 \\
McBurney & 25 & 229 & 254 \\
Laparoscopy & 127 & 869 & 996 \\
\hline Grand total & 223 & 1676 & 1899 \\
\hline
\end{tabular}


Table 3. Negative-positive appendectomies by surgical approach in pediatric and adult population (2009-2016)

\begin{tabular}{|l|l|l|l|}
\hline \multirow{2}{*}{ Age (yrs)/Approach } & \multicolumn{3}{|c|}{} \\
\cline { 2 - 4 } & Yes & No & Total \\
\hline$<16$ & 29 & 620 & 649 \\
McBurney & 6 & 161 & 167 \\
Laparoscopy & 23 & 459 & 482 \\
\hline$>16$ & 63 & 1187 & 1250 \\
McBurney & 11 & 243 & 254 \\
Laparoscopy & 52 & 944 & 996 \\
\hline Grand total & 92 & 1807 & 1899 \\
\hline
\end{tabular}

Table 4. Perforated appendicitis in pediatric and adult population (2009-2016)

\begin{tabular}{|l|l|l|l|}
\hline \multirow{2}{*}{ Age (yrs)/Approach } & \multicolumn{3}{|c|}{} \\
\cline { 2 - 4 } & Yes & No & Total \\
\hline$<16$ & 74 & 575 & 649 \\
McBurney & 33 & 134 & 167 \\
Laparoscopy & 41 & 441 & 482 \\
\hline$>16$ & 144 & 1106 & 1250 \\
McBurney & 40 & 214 & 254 \\
Laparoscopy & 104 & 892 & 996 \\
\hline Grand total & 218 & 1681 & 1899 \\
\hline
\end{tabular}

open: $18.0 \%$ vs. $14.2 \%(\mathrm{p}=0.15)$; negative-negative appendectomy rate (children) - lap vs. open: $11.6 \%$ vs. 9.0\% ( $\mathrm{p}=0.36)$; negative-negative rate appendectomy rate (adults) - lap vs. open: $12.8 \%$ vs. $9.8 \%$ ( $\mathrm{p}=0.21$ ); negative-positive appendectomy rate (children) - lap vs. open: $4.8 \%$ vs. $3.6 \%(\mathrm{p}=0.53)$; negative-positive appendectomy rate (adults) - lap vs. open: $5.2 \%$ vs. $4.3 \%$ $(\mathrm{p}=0.56)$; and lap group negative appendectomy rate in children vs. adults $-16.4 \%$ vs. $18.0 \%$ ( $\mathrm{p}=0.56)$.

Table 4 shows that 218 (11.48\%) of 1899 appendectomies presented as perforated appendicitis, including $73(17.34 \%)$ of 421 open appendectomies and 145 (9.81\%) of 1478 laparoscopic appendectomies. There was a statistically significantly higher rate of perforation in the open approach group $(\mathrm{p}<0.0001)$. There were $74(11.40 \%)$ perforations in 649 pediatric appendectomies, $33(19.76 \%)$ of 167 in the open approach group versus 41 (8.51\%) of 482 in the laparoscopic approach group. There was a statistically significantly higher rate of perforation with open approach in children $(\mathrm{p}<0.0001)$. In the adult population with 1250 procedures, there were 144 (11.52\%) perfora- tions, including $40(15.75 \%)$ of 254 in the open approach group versus 104 (10.44\%) of 996 in the laparoscopic approach group. A statistically significantly higher rate of perforation was recorded with open approach in adults $(\mathrm{p}=0.02)$. Analysis of laparoscopic approach confirmed $104(10.44 \%)$ perforations in 996 adult cases versus 41 (8.51\%) perforations in 482 pediatric cases. There was no statistically significant difference in perforation rate with laparoscopic approach between adult and pediatric populations $(\mathrm{p}=0.24)$. Analysis of open approach confirmed 40 (15.75\%) perforations in 254 procedures in adults versus 33 (19.76\%) perforations in 167 procedures in children. There was no statistically significant difference in the rate of perforation with open approach between adult and pediatric populations $(\mathrm{p}=0.29)$.

\section{Discussion}

Appendectomy remains the method of choice for suspicion or evidence of acute appendicitis in all age groups and all degrees of inflammation, supported by current guidelines and recommendations $s^{4-6}$. With a significantly higher efficacy and low complication rates, appendectomy remains the most effective treatment for patients with uncomplicated acute appendicitis compared to antibiotic treatment ${ }^{10}$. All these guidelines additionally recommend laparoscopic appendectomy as the method of choice with proven benefits compared to open appendectomy for acute appendicitis in adults ${ }^{11}$. The laparoscopic approach is feasible, safe and effective, and may decrease costs in cases of complicated (gangrenous/perforated) appendicitis, with adequate experience and appropriate laparoscopic skills ${ }^{12}$. Several findings support the evidence that, by inflicting fewer traumas when using laparoscopy, the healing response is more efficient, especially in septic patients ${ }^{13}$. It can be assumed that the immune response correlates with inflammatory markers associated with injury severity and, as a consequence, the magnitude of surgical interventions may influence clinical outcomes through the production of molecular factors, ultimately inducing a systemic inflammatory response. It is known that surgical stress response and postoperative immune function are considerably better after laparoscopy ${ }^{14}$. Open surgery increases the incidence of bacteremia, endotoxemia and systemic inflammation compared with laparoscopy, and causes 
lower transient immune defense, leading to enhanced sepsis in patients undergoing open procedures ${ }^{14}$. Techniques such as single incision laparoscopic appendectomy (SILA) and laparoendoscopic single site (LESS) procedure can be viable options, even in cases of complicated (gangrenous/perforated) appendicitis ${ }^{14}$. The surgical glove port-SILA (SGP-SILA) has proved to be a more cost-effective technique when compared to standard SILA or traditional multi-port laparoscopic appendectomy ${ }^{15}$. Although some evidence suggests that children could benefit from laparoscopic approach, others are concerned with the benefits of laparoscopy and emphasize that both approaches have their advantages and disadvantages ${ }^{16}$. The opponents of the laparoscopic approach point out its two shortcomings. The first is that there are no benefits in various cure indicators, especially in children, and the other is that laparoscopic surgeons indicate early exploration in unclear clinical presentations. Some believe that because of laparoscopy less invasiveness and better exploration of the entire peritoneal cavity, which is impossible through McBurney's incision, laparoscopic surgeons replace observation in unclear cases with early exploration. The group submitted to early laparoscopic exploration also includes women with acute or chronic pain in the lower right quadrant, which could lead to a higher rate of negative appendectomy but also to the high rate of positive other intra-abdominal pathology ${ }^{17}$. The results of various studies are contradictory; some argue for a higher rate $^{7}$, whereas others speak of lower rates of negative appendectomy using laparoscopic appendectomy ${ }^{8,9}$. So far, very few papers have been published that compare only the type of approach with the rate of negative appendectomy. Most studies attempt to reduce the rate of negative appendectomy using more precise clinical, clinical-laboratory and clinical-laboratory-radiological (scoring) systems ${ }^{18,19}$. Using modern imaging diagnostic methods, the rate of negative appendectomy has decreased but is not eliminated. Thus, a 10 -year national study from the United States undertaken due to a rise in the use of abdominal computed tomography (CT) in cases of suspected acute appendicitis observed a decrease in the rate of negative appendectomy from $15 \%$ in 1998 to $9 \%$ in $2007^{20}$. However, in countries where abdominal CT is not a recommended diagnostic method for suspected acute appendicitis, the rate of negative appendectomy is high, ranging from $21 \%$ to $26 \%{ }^{21-23}$.
The results of this 8-year study (2009-2016) performed at Zagreb University Hospital Centre showed a continuous increase of laparoscopic appendectomies (from $37.3 \%$ to $92.7 \%$ ). Patients were divided into two large groups (children aged $<16$ and adults aged $>16$ ). Several negative appendectomy variables were analyzed to get an accurate insight into the issue because the rate of total negative appendectomy is not a good indicator of successful diagnosis of acute appendicitis. There are two issues here. The first is that diagnostic workup of clinical presentation indicative of acute appendicitis, in a certain percentage cannot exclude or confirm intra-abdominal pathology. In such cases, due to unclear diagnosis, especially in women of generative age, exploration is indicated, with laparoscopy as the best approach because of two basic advantages, i.e. more detailed exploration of all four quadrants of the peritoneal cavity and less abdominal wall trauma. Secondly, patients with acute gynecologic conditions excluded whose clinical presentation indicates exploration are referred to the emergency surgeon. However, in a certain percentage, it is a gynecologic pathology. Therefore, the negative appendectomy parameter was divided into negative-negative where there was no pathologic substrate and negative-positive in which the appendix was normal, but other pathology was found which required exploration in most cases. Therefore, the accurate parameter of negative appendectomy would be negative-negative appendectomy with one additional remark. It is the concept of endoappendicitis. It is about initial inflammatory changes in the mucosa of the appendix, which are sometimes difficult to detect on pathologic specimen examination, so perhaps the true incidence of negative-negative findings may be lower. Also, there is the condition called appendicopathy, which includes neurogenic appendicopathy ${ }^{24}$ and obstructive appendicopathy ${ }^{25}$, where no histologic signs of inflammation exist. A confirmation of this condition is the percentage of the population that have several similar episodes of pain in the right lower abdominal quadrant during life, and this symptomatology disappears after appendectomy even though the pathologic examination shows normal appendix.

In our study, there were no significant differences in either subgroup of negative appendectomy according to surgical approach to appendectomy. Thus, the rates of total negative appendectomy, negative-positive 
appendectomy and negative-negative appendectomy were the same in the laparoscopic and open groups. This applied to both children (aged <16) and adult (aged $>16$ ) populations in the study. There was no statistically significant difference in the overall rate of negative appendectomy between children and adults with laparoscopic approach either. This could partly be explained by the fact that the same emergency surgeons set the indications for laparoscopy in both children and adults. In a similar study conducted at $\mathrm{Du}^{-}$ brava University Hospital, somewhat lower values of overall negative appendectomy were recorded ${ }^{26}$. This could in part be attributed to the lack of treatment of pediatric population in that hospital, and partly to the lack of female population whose initial presentation as acute gynecologic disease is diagnosed and treated at Department of Gynecology and Obstetrics, Zagreb University Hospital Centre. When the acute gynecologic disease is excluded, these patients are referred to Department of Emergency Medicine, Zagreb University Hospital Centre, where exploration is performed by the emergency surgeon if indicated. This process can partly explain the higher rate of negative appendectomy but also positive gynecologic findings. At the same time, laparoscopic approach contributes to a significantly lower rate of perforated appendicitis. Published studies have clearly shown that the group of perforated appendicitis has a higher incidence of complications ${ }^{27}$. One of the possible explanations is that surgeons who perform exclusively open appendectomy indicate exploration later in the course of the disease when clinical presentation definitely shows acute appendicitis, but with the risk of an increased rate of perforated appendicitis. Another explanation is that laparoscopic surgeons may be opting for open access when clinical or imaging diagnosis of perforated appendicitis is likely. Final conclusion could be that laparoscopic approach is the method of choice for both doubtful cases and when acute appendicitis is certain. This is valid for all age groups since it does not contribute to a higher rate of negative appendectomy but contributes to a significantly lower rate of perforated appendicitis. Diagnostic imaging as a factor not analyzed in this study could contribute to an additional explanation of the negative appendectomy rates in the subgroups analyzed. Lower rates of abdominal CT performed in certain groups (women of reproductive age and children) with atypical clinical presentation are expected due to possible consequences of irradiation. Although the results on the use of abdominal CT with the aim of reducing the rate of negative appendectomy are contradictory, most studies show lower negative appendectomy rates ${ }^{28-31}$.

\section{References}

1. Ma KW, Chia NH, Yeung HW, Cheung MT. If not appendicitis, then what else can it be? A retrospective review of 1492 appendectomies. Hong Kong Med J. 2010;16(1):12-7.

2. Sakran JV, Mylonas KS, Gryparis A, Stawicki SP, Burns CJ, Matar MM, et al. Operation versus antibiotics - the "appendicitis conundrum" continues. J Trauma Acute Care Surg. 2017;82 (6):1129-37, https://doi.org/10.1097/TA.0000000000001450

3. Xu J, Adams S, Liu YC, Karpelowsky J. Nonoperative management in children with early acute appendicitis: a systematic review. J Pediatr Surg. 2017;52:1409-15, https://doi.org/10. 1016/j.jpedsurg.2017.05.003

4. Gorter RR, Eker HH, Gorter-Stam MA, Abis GS, Acharya A, Ankersmit $\mathrm{M}$, et al. Diagnosis and management of acute appendicitis. EAES Consensus Development Conference 2015. Surg Endosc. 2016;30(11):4668-90, https://doi.org/10.1007/ s00464-016-5245-7

5. Di Saverio S, Birindelli A, Kelly MD, Catena F, Weber DG, Sartelli M, et al. WSES Jerusalem guidelines for diagnosis and treatment of acute appendicitis. World J Emerg Surg. 2016; 11:34, https://doi.org/10.1186/s13017-016-0090-5

6. Korndorffer JR Jr, Fellinger E, Reed W. SAGES guideline for laparoscopic appendectomy. Surg Endosc. 2010;24(4):757-61, https://doi.org/10.1007/s00464-009-0632-y

7. Akbar F, Yousuf M, Morgan BJ, Maw A. Changing management of suspected appendicitis in the laparoscopic era. Ann R Coll Surg Engl. 2010;92(1):65-8, https://doi.org/10.1308/003 588410X12518836439920

8. Andersson RE. Short-term complications and long-term morbidity of laparoscopic and open appendicectomy in a national cohort. Br J Surg. 2014;101(9):1135-42, https://doi.org/10.1002/bjs. 9552

9. Laustsen JF, Bjerring OS, Johannessen O, Qvist N. Laparoscopic appendectomy during pregnancy is safe for both the mother and the fetus. Dan Med J. 2016;63(8). pii: A5259.

10. Podda M, Cillara N, Di Saverio S, Lai A, Feroci F, Luridiana $\mathrm{G}$, et al. Antibiotics - first strategy for uncomplicated acute appendicitis in adults is associated with increased rates of peritonitis at surgery. A systematic review with meta-analysis of randomized controlled trials comparing appendectomy and nonoperative management with antibiotics. Surgeon. 2017;15(5): 303-14, https://doi.org/10.1016/j.surge.2017.02.001

11. Dai L, Shuai J. Laparoscopic versus open appendectomy in adults and children: a meta-analysis of randomized controlled trials. United Eur Gastroenterol J. 2017;5(4):542-53, https:// doi.org/10.1177/2050640616661931 
12. Di Saverio S, Mandrioli M, Sibilio A, Smerieri N, Lombardi $\mathrm{R}$, Catena F, et al. A cost-effective technique for laparoscopic appendectomy: outcomes and costs of a case-control prospective single-operator study of 112 unselected consecutive cases of complicated acute appendicitis. J Am Coll Surg. 2014;218(3):e51-65, https://doi.org/10.1016/j.jamcollsurg.2013.12.003

13. Karantonis FF, Nikiteas N, Perrea D, Vlachou A, GiamarellosBourboulis EJ, Tsigris C, et al. Evaluation of the effects of laparotomy and laparoscopy on the immune system in intraabdominal sepsis - a review. J Invest Surg. 2008;21(6):330-9, https:// doi.org/10.1080/08941930802438914

14. Di Saverio S. Emergency laparoscopy: a new emerging discipline for treating abdominal emergencies attempting to minimize costs and invasiveness and maximize outcomes and patients' comfort. J Trauma Acute Care Surg. 2014;77(2):338-50, https://doi.org/10.1097/TA.0000000000000288

15. Di Saverio S, Mandrioli M, Birindelli A, Biscardi A, Di Donato L, Gomes CA, et al. Single-incision laparoscopic appendectomy with a low-cost technique and surgical-glove port: "How To Do It" with comparison of the outcomes and costs in a consecutive single-operator series of 45 cases. J Am Coll Surg. 2016;222(3):e15-30, https://doi.org/10.1016/j.jamcollsurg.2015.11.019

16. Zhang S, Du T, Jiang X, Song C. Laparoscopic appendectomy in children with perforated appendicitis: a meta-analysis. Surg Laparosc Endosc Percutan Tech. 2017;27:262-6, https:// doi.org/10.1097/SLE.0000000000000411

17. Lee M, Paavana T, Mazari F, Wilson TR. The morbidity of negative appendicectomy. Ann R Coll Surg Engl. 2014;96(7): 517-20, https://doi.org/10.1308/003588414X13946184903801

18. Kollár D, McCartan DP, Bourke M, Cross KS, Dowdall J. Predicting acute appendicitis? A comparison of the Alvarado score, the appendicitis inflammatory response score and clinical assessment. World J Surg. 2015;39(1):104-9, https://doi.org/10.1007/s00268-014-2794-6

19. Madžar Z, Kopljar M, Madžar T, Mesić M, Muina Mišić D, Čiček S, Zovak M. Sensitivity and specificity of Fenyö-Lindberg and Teicher scores in the diagnosis of acute appendicitis in women. Acta Clin Croat. 2016;55(4):593-9, https://doi.org/10.20471/acc.2016.55.04.09

20. Seetahal SA, Bolorunduro OB, Sookdeo TC, Oyetunji TA, Greene WR, Frederick W, et al. Negative appendectomy: a 10-year review of a nationally representative sample. Am J Surg. 2011;201(4):433-7, https://doi.org/10.1016/j.amjsurg.2010.10.009

21. Levy RD, Degiannis E, Kantarovsky A, Maberti PM, Wells M, Hatzitheofilou C. Audit of acute appendicitis in a black South African population. S Afr J Surg. 1997;35(4):198-202.

22. Rogers AD, Hampton MI, Bunting M, Atherstone AK. Audit of appendicectomies at Frere Hospital, Eastern Cape. South Afr J Surg. 2008;46(3):74-7.

23. Ohene-Yeboah M, Togbe B. An audit of appendicitis and appendicectomy in Kumasi, Ghana. West Afr J Med. 2006;25 (2):138-43.

24. Sesia S, Mayr J, Bruder E, Haecker FM. Neurogenic appendicopathy: clinical, macroscopic, and histopathological presentation in pediatric patients. Eur J Pediatr Surg. 2013;23(3): 238-42, https://doi.org/10.1055/s-0032-1333119

25. Antonakopoulos GN, Edwards C, Panayiotides J. Obstructive appendicopathy: a disease or a congenital entity? J Clin Pathol. 2008;61:874-5, https://doi.org/10.1136/jcp.2007.054213

26. Kolovrat M, Lovrić Z, Bušić Z, Amić F, Čavka V, Servis D, et al. Laparoskopska ili otvorena apendektomija: naša iskustva i pregled literature. Acta Med Croat. 2012;66:383-5. (in Croatian)

27. Andert A, Alizai HP, Klink CD, Neitzke N, Fitzner C, Heidenhain C, et al. Risk factors for morbidity after appendectomy. Langenbecks Arch Surg. 2017;402(6):987-93, https:// doi.org/10.1007/s00423-017-1608-3

28. Raja AS, Wright C, Sodickson AD, Zane RD, Schiff GD, Hanson R, et al. Negative appendectomy rate in the era of CT: an 18-year perspective. Radiology. 2010;256(2):460-5, https:// doi.org/10.1148/radiol.10091570

29. Coursey CA, Nelson RC, Patel MB, Cochran C, Dodd LG, Delong DM, et al. Making the diagnosis of acute appendicitis: do more preoperative CT scans mean fewer negative appendectomies? A 10-year study. Radiology. 2010;254(2):460-8, https://doi.org/10.1148/radiol.09082298

30. Raman SS, Osuagwu FC, Kadell B, Cryer H, Sayre J, Lu DSK. Effect of CT on false positive diagnosis of appendicitis and perforation. N Engl J Med. 2008;358(9):972-3, https://doi.org/10.1056/NEJMc0707000

31. Kim K, Lee CC, Song KJ, Kim W, Suh G, Singer AJ. The impact of helical computed tomography on the negative appendectomy rate: a multi-center comparison. J Emerg Med. 2008; 34(1):3-6, https://doi.org/10.1016/j.jemermed.2007.05.042 


\title{
Sažetak \\ LAPAROSKOPSKA APENDEKTOMIJA NE POVEĆAVA STOPU NEGATIVNE APENDEKTOMIJE UZ NIŽU STOPU PERFORIRANOG APENDICITISA - REZULTATI NA 1899 BOLESNIKA U KBC ZAGREB
}

\author{
G. Augustin, Z. Čižmešija, J. Žedelj, I. Petrović, V. Ivković, A. Antabak, D. Mijatović i M. Škegro
}

Laparoskopska apendektomija metoda je izbora većine stručnih društava zbog dokazanih mnogobrojnih prednosti. Pitanje je da li se u slučajevima nejasne dijagnoze kirurzi ranije odlučuju na laparoskopsku eksploraciju u odnosu na opservaciju zbog manje invazivnosti i bržeg oporavka i eksploracije cijelog abdomena. Na KBC Zagreb retrospektivno je analizirano 1899 bolesnika u razdoblju od 2009. do 2016. godine kod kojih su operacije započete izmjeničnim rezom ili laparoskopskim pristupom (lap) kod sumnje na akutni appendicitis kod djece i odraslih (stariji od 16 godina). Analizirane su: 1) ukupno negativne apendektomije, 2) negativno-negativne apendektomije (uredan apendiks i nije nađena druga patologija) i 3) negativno-pozitivne apendektomije (uredan apendiks, ali je nađena druga patologija). Nije bilo statistički značajne razlike u stopama negativne apendektomije (djeca) - lap prema izmjeničnom rezu ( $\mathrm{p}=0,24)$; negativne apendektomije (odrasli) - lap prema izmjeničnom rezu $(\mathrm{p}=0,15)$; negativno-negativne apendektomije (djeca) - lap prema izmjeničnom rezu $(\mathrm{p}=0,36)$; negativno-negativne apendektomije (odrasli) - lap prema izmjeničnom rezu $(\mathrm{p}=0,21)$; negativno-pozitivne apendektomije (djeca) - lap prema izmjeničnom rezu $(\mathrm{p}=0,53)$; negativno-pozitivne apendektomije (odrasli) - lap prema izmjeničnom rezu $(\mathrm{p}=0,56)$; negativne laparoskopske apendektomije - djeca prema odraslima $(\mathrm{p}=0,56)$. Utvrđena je statistički značajno viša stopa perforacija izmjeničnim rezom ukupno ( $\mathrm{p}<0,0001)$, kod djece do 16 godina $(\mathrm{p}<0,0001)$ i kod odraslih $(\mathrm{p}=0,02)$. Nije bilo statistički značajne razlike u stopi perforacije kod laparoskopskog pristupa između odrasle i dječje populacije $(\mathrm{p}=0,24)$ te stopi perforacije kod pristupa izmjeničnim rezom između odraslih i djece $(\mathrm{p}=0,29)$. Rezultati upućuju na zaključak da niti u jednoj podskupini laparoskopska apendektomija ne rezultira višom stopom negativne apendektomije, no uz niže stope perforiranog apendicitisa pa se laparoskopska apendektomija preporuča kao metoda izbora kod sumnje na akutni apendicitis kod djece i odraslih.

Ključne riječi: Apendicitis; Apendektomija; Laparoskopija; Hrvatska 